\title{
The health impacts of the contemporary manufacturing and service sectors on men and women
}

\author{
Eleni Kampanellou University of York, UK \\ eleni.kampanellou@york.ac.uk \\ Donald Houston University of Portsmouth, UK
}

(Received November $2015 \quad$ Revised March 2016)

http://dx.doi.org/10.14301/llcs.v7i4.392

\begin{abstract}
Manufacturing and manual employment and, to a lesser extent, low-grade white-collar work have long been associated with poor health outcomes. This article reports important new findings based on longitudinal micro data that demonstrate important changes and genderrelated patterns to this prevailing understanding. Specifically, manufacturing employment now has a protective health effect for men, and women's health is not strongly influenced by occupation. High-paid service sector employment is found to be bad for health, particularly among men. Changing industry within the service sector is linked to a deterioration in health, particularly among women, whereas changing employment from manufacturing to services is found to be bad for men's health. Confirming previous research, shifts from any sector of employment into unemployment and economic inactivity are strongly associated with a deterioration in health. The findings point to four conclusions: i) the emergence of new occupational hazards in the service sector; ii) the improvement of working conditions in manufacturing; iii) changing industry is damaging to an individual's health, possibly due to skills mismatches that may arise, although further research is required to further disentangle the direction of causation; and iv) the impacts on health of different industrial sectors and changes between industrial sectors vary between men and women.
\end{abstract}

\section{Keywords}

Gender, health, inactivity, longitudinal studies, morbidity, occupational hazards, unemployment

\section{Introduction}

Manufacturing and construction employment, and to a lesser extent low-grade clerical work, have long been linked with poor health (Hedlund, Järvholm \& Lundbäck, 2006; Hein, Stayner, Lehman \& Dement, 2007; Jones et al., 2009). The transition of developed economies from manufacturing towards services has been associated with mixed health implications (Ostry et al., 2000, 2002). On the one hand, the decline and automation of hazardous occupations and improved health and safety practices in manufacturing and construction have been hypothesised to reduce the incidence of ill-health and disability in the working-age population (Loomis, Richardson, Bena \& Bailer, 2004). On the other hand, work intensification and flexibilisation prevalent in the expanding low-grade service sector may be producing new occupational hazards for health arising from pressure, lack of control and the sedentary nature of non-manual employment (Anderson, Schulte, Sestito, Linn \& Nguyen, 2010; Sekine, Chandola, Martikainen, Marmot \& Kagamimori , 2009).

Industrial decline and associated job destruction impacts adversely on health through unemployment, economic inactivity or reemployment in lower quality jobs in the service sector. Low-grade service sector jobs are often 
characterised by inferior salaries, the health impacts of which may be compounded if individuals coming out of manufacturing are less well suited or equipped to perform the tasks required, for example arising from skills and cultural mismatches (Danson, 2005; Power, 2008; Wessel, 2005). Unemployment and non-participation in the labour market (economic inactivity) are strongly associated with poor health, although the magnitude of causality in each direction remains uncertain - in other words, in some cases job loss comes first and subsequently impacts on health, while in other cases the onset of illness or other conditions subsequently lead to exits from employment (Bambra \& Eikemo, 2009; Booker \& Sacker, 2013; Korpi, 2001).

Previous research on the health implications for individuals of changing the industrial sector in which they are employed has tended to focus on individuals making the transition from manufacturing to services, particularly men, as a result of the deindustrialisation process producing forced job changes (Beatty \& Fothergill, 1996; Morris \& Cook, 1991; Rocha, 2001). Little is known about how other transitions between industrial sectors affect health, nor about how the health impacts of changing industry may affect men and women differently. As with job loss, changes in the industrial sector of employment may be either cause or consequence of poor health - or both. Some individuals may change industry in response to a change in their health-related capacity to perform tasks in their previous job. In other circumstances, a change in industrial sector may occur for reasons unrelated to health but have subsequent impacts on health. In both cases, the effectiveness of the labour market and hiring process in matching workers and jobs in terms of skills and preferences is likely to be important in determining subsequent health outcomes. Good matches could be expected to produce better health outcomes.

The effect of an individual changing industry of employment can be hypothesised to impact on that individual's health in two regards. First, the new industry may be associated with different health outcomes (either better or worse) compared to the old industry, arising from differences in pay, job security and physical and psychosocial hazards. Second, the process of change itself may be stressful, and produce a poorer match between the worker and the job in terms of skills, physical and mental capabilities and personal preferences, which may in turn lead to greater physical and mental stresses. Adapting to change, including a possible drop in income and impact on occupational identity, may bring short- and long-term physical and mental stresses.

Involuntary necessity-driven transitions between industries, for example arising from redundancy, could be expected to produce particularly poor 'matching' of workers to jobs because people facing unemployment experience greater pressure to quickly obtain and accept job offers. Because of lower employability, individuals in weaker socioeconomic circumstances and with lower qualifications could be expected to be more likely to experience involuntary changes in job and/or industry and to experience such changes more frequently over the course of their working lives. Repeated transitions and poor worker/job matching may in combination have cumulative adverse effects on career progression and on health over the life course. The rise of precarious or 'nonstandard' forms of employment (including zerohours contracts, agency work and self-employment) may be over time forcing more people into involuntary changes in job and/or industry. Furthermore, the intensification of work, particularly in the low-skilled end of the service sector, may be producing new occupational hazards for health.

This article has three research aims. First, to update evidence on the link between industrial sector employment and health outcomes. Second, to assess the link between a change in industrial sector and a change in health, going beyond existing research that has focussed on men shifting from manufacturing to service-sector employment. Third, to investigate whether industrial sector and a change in industrial sector affect the patterns of poor health among men and women differently.

\section{Industrial sector, gender and health Industrial sector and health}

Traditional manufacturing industries have been associated with specific physical health conditions (respiratory-related diseases, various malignant neoplasms and injuries) for both males and females (Andersson, Persson, Bryngelsson, Magnuson \& Westberg, 2010; Jones et al., 2009; Stout, Jenkins \& Pizatella, 1996). Some parts of the service sector 
are characterised by casualization and low levels of training and career development, which may lead to 'job stress' and poor health outcomes for both men and women (Ferrie, Shipley, Stansfeld \& Marmot, 2002). The service sector covers a range of sub-sectors associated with diverse health implications. More precisely, high rates of mortality are observed for employees in the wholesale and retail sector (Anderson et al., 2010). Occurrences of heart disease are more frequent among low-grade civil servants, where employees demonstrate higher blood pressure, smoking and limited physical activity (Van Rossum, Shipley, Van de Mheen, Grobbee \& Marmot, 2000).

Additional factors contributing to the prevalence of certain morbidity outcomes are associated with the psychosocial nature of employment. Supplementary elements such as job insecurity and high work-related demands combined with low control and rewards at work are linked with the increase of incidents of coronary heart diseases, sickness absences, emotional exhaustion and overall life dissatisfaction (Aronsson, Gustafsson \& Dallner, 2002; Kuper \& Marmot, 2003; Sekine et al., 2009; Van der Hulst \& Geurts, 2001).

Recent research has revealed that the nature of work in both manufacturing and in the service sector has changed (Murray, Baldwin, Ridgway \& Winder, 2005; Ostry et al., 2001). Qualitative evidence suggests that these changes may be altering established employment-related patterns of health - but this has not been quantitatively tested (Ostry et al., 2002). Specifically, automation in manufacturing and construction and improved health and safety practices in hazardous industries may have reduced hazards, and certainly injuries and fatalities reported by industries have fallen (Loomis et al, 2004). Meanwhile, work intensification and flexibilisation prevalent in the service sector may have increased adverse impacts on health (Baumberg, 2014). Work intensification may have increased work-related stress, while aspects of flexibilisation may have led to greater insecurity and an increase in involuntary job changes (Benach, Muntaner \& Santana, 2007; Booth, Francesconi \& Frank, 2002; Marmot \& Bell, 2010).

Deindustrialisation has resulted in high levels of job loss and redundancy, which are strongly linked with poor health (Brown et al., 2012). Unemployed individuals are more likely to demonstrate physical and psychological morbidity (Bambra \& Eikemo, 2009; Bartley, 1994; Eliason \& Storrie, 2009). On the one hand this association arises because preexisting ill-health increases the probability of unemployment compared to healthy individuals (Arrow, 1996; Lindholm, Burström \& Diderichsen, 2001; Stewart, 2001). On the other hand, unemployment increases unhealthy behaviour driven by anxiety and financial strain (Kessler, Turner \& House, 1989; Montgomery, Cook, Bartley \& Wadsworth, 1998; Morris, Cook \& Shaper, 1994; Rocha, 2001). In addition to unemployment, the sharp decline of manufacturing jobs, pre-existing poor health, the lack of transferable skills of former manufacturing employees, and increased work demands in the service sector in combination led to the acceleration of inactivity rates and claiming of disability-related benefits (Baumberg, 2014; Beatty \& Fothergill, 1996; Fieldhouse \& Hollywood, 1999), initially mainly among men and later also among women (Beatty, Fothergill \& Powell, 2008).

\section{Gender, employment and health}

The shift from a largely manufacturing-based to a largely service-based economy has been accompanied by an increase in the labour participation of women - especially in the lowergrade service sector (Marmot et al., 1991), which has been linked with poor health outcomes. In employment, men are more likely to experience higher demands for commitment and responsibility but also higher levels of control; women are more likely to experience higher emotional demands along with greater levels of routinisation, lower salaries and greater insecurity (Campos-Serna, Ronda-Pérez, Artazcoz, Moen \& Benavides, 2013; Siegrist et al., 2004).

The gendered division of the labour market has led to an extensive literature looking at the nature and health consequences of the working environment for men and women. Women tend to report higher levels of physical and mental ill-health arising from their job (Menéndez, Benach , Muntaner, Amable \& O'Campo ,2007; Vermeulen \& Mustard, 2000), particularly musculoskeletal health problems arising from repetitive tasks (Wijnhoven, De Vet \& Picavet, 2006). Greater reporting of poor health could be due to the nature of the job, but also due to women more generally reporting poorer health than men, arising from differences in the self-perception of heath and the biological attributes of males and females (Krieger, 2003). 
The greater reporting by women of employmentrelated poor health may be partly the result of the additional burden of domestic work, including mainly household responsibilities and caretaking activities, which can result in emotional burnout in an attempt to balance work and family obligations (Bartley, 1999; Campos-Serna et al., 2013; MaderoCabib, 2015).

Experiences of working environments are gendered. Men and women are often treated differently in otherwise identical jobs, and men and women tend to place different levels of value on various aspects of the work environment. Specifically, women place more value on good working relationships and the absence of long hours, while men consider remuneration as more important (Bender, Donohue \& Heywood, 2005). These gendered dimensions of the workplace can result in men and women experiencing ostensibly the 'same' job somewhat differently. Coupled with biological differences in susceptibility to different health conditions, men and women's health may be impacted differently in similar workplaces (Benach et al., 2007; Kreimer, 2004).

\section{Job changes and health}

Most of the literature on the health impacts of industrial sector of employment is quite static and does not consider the impact of switching employment between sectors. Workers are becoming more mobile across and within sectors, making the static approach increasingly problematic.

Research indicates that for men a shift from manufacturing to service-sector employment can lead to skills mismatches and be detrimental in terms of their identity and wellbeing (De Grip, Bosma, Willems \& Van Boxtel, 2008). The notion that job shifts between industrial sectors more generally (i.e. not only from manufacturing to services), including at a finer scale within broad groupings such as 'manufacturing' and 'services', has not been assessed in existing literature. In addition, existing literature considering the impact of a shift from manufacturing to service-sector employment has (to some extent justifiably given the dominance of men in manufacturing) focussed on men and largely ignored women (Nixon, 2006; Sayce, Ackers \& Green, 2007).

The effectiveness of the labour market and hiring decisions in achieving good matches between workers and jobs in terms of skills, experience and preferences is likely to impact on subsequent health outcomes. Similarly, training provision and support for staff development once in post is likely to impact on skills mismatches, skill deficiencies and job satisfaction (Stier \& Yaish, 2014; Zou, 2015). Hiring practices, labour market tightness, credentialism and staff development vary by industry and are gendered (Fernandez \& Mors, 2008; Hampson \& Junor, 2010; Hoque \& Kirkpatrick, 2003; Scherer, 2004). Some existing studies have detected a link between skills mismatch and job satisfaction (Jones, Jones, Latreille \& Sloane 2009; Liljegren \& Ekberg, 2010), and job satisfaction is likely to subsequently influence health outcomes.

Changing sector of employment may represent a beneficial adjustment mechanism in response to health-damaging or otherwise unsatisfactory employment. A change in the sector of employment may in some circumstances lead to a better match between the skills, preferences and capabilities of an individual and the nature and demands of their job. In other circumstances, however, the decision to change sector of employment may lead to a deterioration, rather than improvement, in the fit between the worker and job. Poor matches between worker and job could be expected to be more likely when the decision to change sector is, at least to some degree, forced upon an individual, for example in response to job loss (Gesthuizen \& Dagevos, 2008; Kristensen \& Westergaard-Nielsen, 2004).

In the case of re-employment following involuntary job loss, existing evidence points towards mixed health outcomes. Re-employment of former industrial employees to similar jobs contributed to the formation of a positive physical and psychological health experience compared to employees absorbed to less desired jobs (Ostry et al., 2002; Riva, Terashima, Curtis, Shucksmith \& Carlebach , 2011). Consequently, the nature of job, in the case of re-employment, combined with elements of job satisfaction and the level of skills mismatch, has significant health impacts. The training and qualification credentials required to enter an industry and the level of training and staff development offered once hired are likely to play a role in minimising 'job stress' and associated adverse health outcomes.

An important distinction between changing sector and exiting employment (the latter has been linked with adverse health outcomes) is the degree 
of agency involved. Although many exits from employment involve the exercise of agency on the part of the (former) worker and may even be positive choices or in others necessitated by a deterioration in health, in many cases leaving employment is involuntary, for example as the result of compulsory redundancy. In contrast, changing occupation (almost by definition) requires some agency on the part of the worker to choose and secure employment in an alternative sector even if the initial trigger was an external factor such as job loss. An individual changing sector of employment may be doing so voluntarily or involuntarily - or making a constrained choice lying somewhere in-between. The degree of voluntariness, the extent to which agency can be exercised and the level of opportunities available in a given local labour market, all influence the likelihood that a change in occupation will lead to an improvement or deterioration in the goodness of fit between worker and job, and the attendant health impacts that may arise from that goodness or badness of fit.

\section{Methods}

\section{Research design}

Previous studies of the impacts of employment sector and changes in industrial sector of employment are characterised by selection effects and short-term duration of follow-up, and focus mainly on former male manufacturing employees (Morris \& Cook, 1991). This is problematic because less healthy workers might not have the same chances of becoming re-employed or entering their favoured alternative occupations compared to their healthy counterparts. In the same context, the short duration of follow-up of those studies does not allow for long-term effects.

This study employs a longitudinal design, with a cohort of employed individuals observed at the beginning and end of a ten-year period, in order to mitigate these limitations in the existing literature. Our research design seeks to explain the probability of an individual reporting poor health at the end of the ten-year period. The key variables of interest on our models relate to industry and change in industry of employment. We control for the existence of a health condition at the beginning of the ten-year period that limits activities, which goes some way to combatting uncertainty in the direction of causation by isolating the effect of employment change on health as opposed to the effect of health in inducing change in employment.

The ideal research design would involve repeated observations at a number of points in time in order to identify the sequencing of changes in sector of employment and health. Unfortunately, such data available in British Household Panel Survey (BHPS) at the time of analysis had insufficient numbers of observations of persons moving between industrial sectors. Therefore, we used the larger number of longitudinally linked Census records available in the Scottish Longitudinal Study (SLS). Future research could make use of the expanded sample size in the UK Household Longitudinal Survey (UKHLS) which replaced the BHPS in 2009, although the SLS, at least for the time being, retains the advantage of spanning a longer time period.

Scotland was chosen as a region that has experienced substantial industrial restructuring, including large numbers coming out of manufacturing throughout the 1990s and growth of a low-paid service sector, and suffers from extensive poor health. Scotland has the added benefit of the availability of the SLS, which has a large sample drawn from Census records (a much larger proportion of the Scottish population is included than in the English Longitudinal Study) and tracks individuals over a long period. At the time of analysis, the 1991 and 2001 Censuses of Population were linked and available within the SLS.

\section{Sample}

The Scottish Longitudinal Study represents 5.3\% of the Scottish population and information is collected from the Scottish Census and administrative sources (SLS-DSU, 2013). The analysis reported in this article includes two time points, 1991 and 2001. The sample used in this analysis involves the working age employed population (defined as 20-54 in 1991 in order to minimise the inclusion of those still in full-time education and those who retire within the ten-year period of observation) in the secondary and tertiary sectors in the year 1991 (i.e. the primary sector comprising agriculture, forestry and fishing was excluded). The sample selection incorporated only those employed in the year 1991.

Restricting the sample to employed persons only reflects the objective to understand the impact on health of industry and change in industry. Nonemployed individuals at the start of the period of 
observation (1991) are not exposed to occupational hazards, therefore are not included in our analysis (individuals employed in 1991 but not in 2001 remain in the sample, although results are not reported in the interests of space and because the links between non-employment and poor health are already well documented in existing literature).

Furthermore, individuals who were not in employment in 1991 could not, by definition, display a change in industry - a key 'treatment' in our research design (to use experimental design terminology) - when observed for the second time in 2001. For the same reason, we exclude workers over the age of 54 in 1991 as most will have retired by 2001 and therefore could not display a change in industry. We excluded from our sample individuals aged under 20 years in 1991 on the basis that a high proportion are still in education or have not yet settled on an occupation or industry. Our results, therefore, relate to employed persons aged 20-54 years and not the working-age population as a whole, although include those who have exited employment for unemployment or economic inactivity at the end of the ten-year observation period.

Those who died or left the sample for other reasons were not incorporated into the analysis. Mortality is recorded in the SLS but was not modelled as an adverse health outcome due to insufficient numbers of observations. Employees in full or part-time employment, self-employed with or without employees and those on a government scheme were included in the baseline sample of employed individuals. The sample of the individuals appearing in both the 1991 and 2001 Censuses comprised of 63,150 persons. The number of males was 32,968 and covered $52 \%$ of the sample, whereas the number of women was 30,182 (48\%).

\section{Health measures (outcome or dependent variable)}

Health is captured in the 2001 Scottish Census by self-assessed health over the previous 12 months. The question is: 'Overall the last twelve months would you say your health has on the whole been?' (SLS-DSU, 2013). It has three possible responses: 'good', 'fairly good' or 'not good'. For binary logistic regression analysis, the self-assessed health responses have been transformed into a binary dependent variable: 'good/fairly good' or 'not good'. Self-assessed health is widely used in epidemiological research and longitudinal studies as a good indicator of premature mortality (Burström
\& Fredlund, 2001) and has been chosen for two reasons. First, it may indicate aspects or symptoms of ill-health not always detectable or yet diagnosed in formal medical procedures (Idler \& Benyamini, 1997). Second, it reflects physical and mental conditions related to lifestyle choices and psychosocial influences on health (Eriksson, Unden \& Elofsson, 2001; Mackenbach, Van den Bos, Joung, Van de Mheen \& Stronks, 1994). Overall, the use of self-assessed health in other studies has shown good reliability (Lahelma, Maritkainen, Laaksonen \& Aittomäki, 2004; Lundberg \& Manderbacka, 1996). Regarding the Scottish census, a cognitive question testing was conducted by Ipsos MORI Scotland and it was concluded that this question is effective (Scotland's Census, 2015).

Also captured is liming long-term illness (LLTI), which is based on binary (yes/no) responses to the question, 'Do you have any long-term illness, health problem or disability which limits your daily activities or the work you can do?' (SLS-DSU, 2013). We modelled outcomes based on both selfassessed health and LLTI, which produced very similar results. We report the results for selfassessed health in the main body of the article and the results for LLTI in annexes.

\section{Sectoral stability and change (key explanatory variable of interest)}

The manufacturing sector was sub-divided into 'mining and manufacturing' and 'energy and construction' (table 1). The service sector was subdivided into high and low-paid occupations (see Annex 3 and Holdsworth, 2010). Employed individuals in the year 1991 were followed up in 2001 and this formed an indicator based on stability or change between four employed states (two manufacturing sectors and two service sectors). The influences of leaving employment for unemployment or economic inactivity were also modelled, but these have not been reported in the interests of clarity and length and because the health impact of employment exits are well documented. The indicator of stability or change is based on four possible states in 1991 (the four occupational groups) and six possible states in 2001 (the four occupational groups plus the two nonemployed states of unemployed or inactive). This produces a $4 \times 6$ matrix of possibilities, i.e. 24 possible combinations of states across the two 
years of observation. All groups are mutually exclusive.

For moves in and out of manufacturing, the two manufacturing groups have been combined in order to maintain an adequate sample size. Again because of sample size constraints we have not differentiated between upward and downward mobility within manufacturing or within services (although our sub-division of manufacturing is not hierarchal in any case), but rather created categories that indicate whether there has been a change in occupation within the broad manufacturing and services categories. These amalgamations of cells in the 24-cell matrix reduce the total number of stability or change categories to 16. Six of these are exits from employment which have not been reported, leaving the ten occupational stability and change groups reported in each model in the results section. The models include a number of control variables relating to demographic, socioeconomic and pre-existing (1991) health (see next section), but these have not been reported in the interests of clarity and space.

\section{Table 1. Population groups} Groups

Employed in Mining/Manufacturing both years

Employed in Construction/Energy both years

Changed Industry

Employed in High-Paid Services in 2001 (From Industry 1991)

Employed in Low- Paid Services in 2001 (From Industry 1991)

Employed in Industry in 2001

(From High-Paid Services 1991)

Employed in Industry in 2001

(From Low-Paid Services 1991)

Employed in High-Paid Services both years Employed in Low-Paid Services both years Changed Services

\section{Description}

Same sector both in 1991 \& 2001

Same sector both in 1991 \& 2001

From/To: Mining/Manufacturing 1991/2001

To/From: Construction/Energy 2001/1991

From: Industry 1991

To: High Paid Services in 2001

From: Industry 1991

To: Low-Paid Services in 2001

From: High Paid Services 1991

To: Industry in 2001

From: Low- Paid Services 1991

To: Industry in 2001

Same sector both in $1991 \& 2001$

Same sector both in 1991 \& 2001

From/To: High-Paid Services 1991/2001

To/From: Low-Paid Services 2001/1991
Total

6162

3246

1059

3017

2195

1294

1542

19449

7670

5383

Source: Scottish Longitudinal Study

\section{Control variables}

The analysis controlled for socioeconomic and demographic indicators that acted as confounding factors when examining the influence on health of sector and change in sector of employment. The determinants of health cover a range of factors that encompasses the social and economic environment, the physical environment as well as the individual level characteristics and behaviour. Age and gender are well-known determinants of health. The younger the age of an individual, the higher the probability of him/her being healthy and being part of the labour market. Moreover, gender plays an additional part, since men and women tend to suffer from different morbidity events, have diverse health expectations and be frequently involved in different occupational tasks (WHO, 2016).
An important socioeconomic factor across the life course is education. Low levels of education are linked to poor health, fewer career prospects and therefore challenging economic circumstances. The lack of adequate educational qualifications can hinder the accessibility to additional necessities such as housing (Bambra, Gibson, Sowden, Wright, Whitehead \& Petticrew, 2010). Housing assets, especially building type, number of rooms and ownership have been frequently used as indicators of wealth, instead of income, and have been linked to reduction in injuries, increase in overall wellbeing and social participation (Macintyre, Ellaway, Hiscock, Kearns, Der \& McKay, 2003).

As with high living standards, stable and supportive personal relationships, proxied by marital status, can positively influence health. Being 
married can act as a source of health-promotion, where individuals tend to adopt healthier lifestyle choices and through social support improve their overall wellbeing (Kiecolt-Glaser \& Newton, 2001). Moreover, marriage can enhance household income and therefore provide accessibility to additional material resources and protection against individual level poverty (Lahelma et al., 2004).

More precisely, as well as gender, age was divided in five year intervals, and marital status contained three categories (single, married/remarried, divorced/widowed). Additional indicators such as educational qualifications and car ownership controlled for differences between individuals in socioeconomic status. Educational qualifications were split in three categories: First/Higher, other and no qualifications. The first category includes all the individuals with professional or university degrees/diplomas and those with Higher National Certificates (HNC/HND/SVQ level 4 or 5). Other category refers to those with a Certificate of Sixth Year Studies (CSYS), A-levels together with vocational qualifications (GSVQ/SVQ) and Ordinary National Certificates (ONC/OND Level 3). The final category involves all those without any qualifications, those with General Certificate of Secondary Education (' $O$ ' Grade) and those with vocational qualifications (Level 1).

Likewise, housing conditions such as tenure, number of rooms and heating facilities were supplementary indicators of economic status (Annex 4 includes additional descriptive information). Finally, some models controlled for pre-existing limiting long-term illness in 1991, on the basis that ill-health that limits activities could accelerate the transition towards inactivity and induce health-related changes in occupation (table 2). Unfortunately, the self-assessed health question was not introduced in the 1991 census. In addition to initial models with gender as a control variable, separate models were also run for men and women.

\section{Table 2. Control variables}

\begin{tabular}{ccc} 
Variables & Categories & Labels \\
\hline Age & $20-24$ 25-29 30-34 35-39 40-44 & Age 1991 \\
Marital Status & S5-49 50-54 & Marital Status 1991 \\
Education & Widowed-Divorced & \\
& First or Higher Education \\
Other Non-Degree & Qualifications 1991 \\
Nousing Tenure & Owner/Private rented/ Social rented & \\
Rooms & Two or less / Three /Four or more & Housing Tenure 1991 \\
Cars & Owns a car /Does not own a car & Number of Rooms 1991 \\
Central Heating & Has central heating / No central heating & Car ownership 1991 \\
LLTI & No/Yes & Central Heating 1991 \\
\hline
\end{tabular}

Source: Scottish Longitudinal Study

\section{Analysis}

Logistic regression was used for the analysis. The dependent variable is coded as 1 if health is reported as 'not good' and 0 if 'good' or 'fairly good'. Therefore, odds ratios reported relate to the probability of reporting poor health - the higher the odds ratio, the more likely that health is poor. The reference category in relation to the sector and sectoral change categories is 'remained in manufacturing' - odds ratios less than 1 mean poor health is less likely than for those who remained employed in manufacturing over the ten-year period, while odds ratios greater than 1 mean poor health is more likely than for those who remained employed in manufacturing over the ten-year period.

Table 3 reports three models. Model 1 controls for demographic measures (age, gender and marital status). Model 2 also controls for the socioeconomic indicators mentioned in the previous section. Model 3 adds a control for preexisting limiting long-term illness. Coefficients and odds ratios are stable across the three models, suggesting the model is robust. Table 4 reports 
separate models for men and women, which included the full suite of control variables (i.e. as model 3 in table 3 , excluding the gender variable of course).

\section{Results}

The results indicate that manufacturing employment has a protective effect on health compared to employment in any part of the service sector. With all controls in place, those who remained in high-paid service sector employment over the ten-year period are most likely of all sectoral stability and change groups to report 'not good' health, and are 1.45 times more likely to report poor health than those who remained in the manufacturing sector (model 3, table 3). Even only controlling for demographic factors and not socioeconomic characteristics, high-paid service workers remain 1.20 times more likely to report poor health than manufacturing workers (model 1 , table 3). After manufacturing, stable employment in low-paid services offers the second-best protective effect for health, with an odds ratio not statistically significantly different to stable manufacturing (model 3, table 3). However, without controlling for socioeconomic factors (model 1, table 3), low-paid service workers are 1.22 times more likely to report poor health than manufacturing workers and this is statistically significant at the $95 \%$ level.

Although not shown in the table, men have a higher odds ratio $(1.51 \mathrm{p}<0.05$, model 3 , table 3 ) of reporting poor health compared to women. Descriptive statistics without any controls indicate that women report slightly more poor health than men $18.31 \%$ of women in our sample compared to $8.18 \%$ of men reported their health was 'not good' in 2001).

\section{Table 3. Influence of industry and change in industry on self-assessed health}

\begin{tabular}{|c|c|c|c|}
\hline Activity 2001 & Model 1 & Model 2 & Model 3 \\
\hline \multicolumn{4}{|l|}{$\begin{array}{c}\text { Employed in Mining/Manufacturing } \\
\text { both years (base) }\end{array}$} \\
\hline $\begin{array}{l}\text { Employed in Construction/Energy } \\
\text { both years }\end{array}$ & $0.85(0.65-1.11)$ & $0.83(0.64-1.09)$ & $0.85(0.65-1.11)$ \\
\hline Changed Industry & $0.49(0.28-0.83)^{* *}$ & $0.46(0.27-0.79)^{* *}$ & $0.47(0.27-0.80)^{* *}$ \\
\hline $\begin{array}{l}\text { Employed in High-Paid Services } 2001 \\
\text { (from Industry 1991) }\end{array}$ & $0.92(0.69-1.21)$ & $0.97(0.73-1.28)$ & $0.96(0.72-1.26)$ \\
\hline $\begin{array}{l}\text { Employed in Low-Paid Services } 2001 \\
\quad \text { (from Industry 1991) }\end{array}$ & $1.31(0.99-1.73)^{*}$ & $1.26(0.95-1.66)$ & $1.24(0.94-1.64)$ \\
\hline $\begin{array}{l}\text { Employed in Industry } 2001 \\
\text { (from High-Paid Services 1991) }\end{array}$ & $1.01(0.69-1.46)$ & $1.07(0.74-1.55)$ & $1.06(0.73-1.53)$ \\
\hline $\begin{array}{c}\text { Employed in Industry } 2001 \\
\text { ( from Low-Paid Services 1991) }\end{array}$ & $1.00(0.70-1.42)$ & $0.94(0.66-1.34)$ & $0.94(0.66-1.34)$ \\
\hline Employed in High-Paid Services both years & $1.20(1.01-1.43)^{*}$ & $1.46(1.23-1.74)^{* *}$ & $1.45(1.22-1.73)^{* *}$ \\
\hline Employed in Low-Paid Services both years & $1.22(0.99-1.49)^{*}$ & $1.17(0.96-1.43)$ & $1.15(0.94-1.41)$ \\
\hline Changed Services & $1.39(1.12-1.72)^{* *}$ & $1.40(1.13-1.74)^{* *}$ & $1.38(1.11-1.71)^{* *}$ \\
\hline \multicolumn{4}{|l|}{$\begin{array}{c}\text { Diagnostics (for full models including control } \\
\text { variables and non-employed outcomes not } \\
\text { reported) }\end{array}$} \\
\hline Pseudo R-squared & 0.2381 & & \\
\hline $\mathrm{N}$ & 63,150 & & \\
\hline LR Chi-Square(33) & $8,096.70$ & & \\
\hline Prob $>$ Chi-Square & $<0.0000$ & & \\
\hline
\end{tabular}

${ }^{*} .01<p<.05 * * p<.01$. Model 1: age and sex controls; Model 2: age, sex and socioeconomic controls; Model 3: age, sex, socioeconomic and LLTI controls. Results: odds ratios and confidence intervals. Source: Scottish Longitudinal Study 
In order to investigate whether the patterns of poor health among men and women are affected differently by industry or change in industry, we ran separate models for men and women. These are reported in table 4 . The models identify patterns of poor health among men and women across industry and change in industry groupings. This allows us to conclude, for example, that industrial differences in male health are wider than for women. It does not, however, allow us to conclude that industry $X$ is better or worse for men's health than for women's health. In other words, odds ratios for men and women cannot be directly compared along the rows in table 4 but the patterns up and down the columns can be compared. This is because odds ratios calibrate relative rather than absolute differences between the industry/change in industry groups.

For women, there are no statistically significant differences between industrial groups in likelihood of reporting poor health. Nevertheless, despite not being statistically significant, low-paid services appear to be the best type of employment for women's health (on the basis of having lowest odds ratio (0.92) of all the stable occupational groups for women in table 4). This is in contrast to manufacturing or construction which appears to be best for men's health (on the basis of both stable service sector groups for men having odds ratios greater than 1.0 compared to stable manufacturing - 1.40 and 1.13 for high- and low-paid services, respectively in table 4 ).

The R-squared for the model for women in table 4 is lower than that for men $(0.197$ for women compared to 0.288 for men) - in other words, sector of employment explains less health variation among employed women than it does among men. Men and women who change sector within manufacturing are less likely to report 'not good' health than those who remain within the same manufacturing sub-sector (odds ratio of 0.47 for men and 0.65 for women - although only statistically significant for men - table 4). The opposite is true in the service sector, where changing sector is associated with a 1.38-times increase in the probability of reporting poor health (model 3, table 3).

In terms of moves between manufacturing and services, there are again differences between the two broad sectors. A move from manufacturing to low-paid services is associated with a deterioration in health (odds ratio of 1.24 in model 3, table 3 not statistically significant in model 3 but significant in model 1 when socioeconomic controls are removed), and this is true for men and women (table 4). In contrast, a move in the opposite direction from low-paid services to manufacturing appears to have little or no impact on health, although a small but not statistically significant benefit for men is detectable (odds ratio for men in table 4 is 0.82 compared to 1.13 for men remaining in low-paid services). Although not statistically significant, a move from high-paid services to manufacturing appears to be beneficial for men's health (odds ratio 0.92 compared to 1.40 if remaining in high-paid services) but damaging to women's health (odds ratio of 1.29 compared to 1.15 if remaining in high-paid services). 
Table 4. Influence of industry and change in industry on self-assessed health by Gender

\begin{tabular}{|c|c|c|}
\hline Activity 2001 & Men & Women \\
\hline \multicolumn{3}{|l|}{$\begin{array}{c}\text { Employed in Mining/Manufacturing both } \\
\text { years (base) }\end{array}$} \\
\hline Employed in Construction/Energy both years & $0.90(0.68-1.20)$ & $0.96(0.37-2.48)$ \\
\hline Changed Industry & $0.47(0.26-0.85)^{* *}$ & $0.65(0.15-2.77)$ \\
\hline $\begin{array}{l}\text { Employed in High-Paid Services } 2001 \\
\text { (from Industry 1991) }\end{array}$ & $0.94(0.67-1.32)$ & $0.93(0.56-1.54)$ \\
\hline $\begin{array}{l}\text { Employed in Low-Paid Services } 2001 \\
\text { (from Industry 1991) }\end{array}$ & $1.22(0.88-1.70)$ & $1.11(0.67-1.85)$ \\
\hline $\begin{array}{c}\text { Employed in Industry } 2001 \\
\text { (from High-Paid Services 1991) }\end{array}$ & $0.92(0.57-1.47)$ & $1.29(0.69-2.40)$ \\
\hline $\begin{array}{c}\text { Employed in Industry } 2001 \\
\text { ( from Low-Paid Services 1991) }\end{array}$ & $0.82(0.52-1.31)$ & $0.99(0.56-1.76)$ \\
\hline Employed in High-Paid Services both years & $1.40(1.13-1.75)^{* *}$ & $1.15(0.82-1.59)$ \\
\hline Employed in Low-Paid Services both years & $1.13(0.88-1.47)$ & $0.92(0.64-1.31)$ \\
\hline Changed Services & $1.15(0.84-1.58)$ & $1.16(0.81-1.67)$ \\
\hline \multicolumn{3}{|l|}{$\begin{array}{c}\text { Diagnostics (for full models including control } \\
\text { variables and non-employed outcomes not } \\
\text { reported) }\end{array}$} \\
\hline Pseudo R-squared & 0.2877 & 0.1967 \\
\hline $\mathrm{N}$ & 32,968 & 30,182 \\
\hline LR Chi-Square(32) & $5,080.68$ & $3,213.83$ \\
\hline Prob > Chi-Square & $<0.0000$ & $<0.0000$ \\
\hline
\end{tabular}

${ }^{*} .01<p<.05{ }^{* *} p<.01$. Model includes age, socioeconomic and LLTI controls. Results: odds ratios and confidence intervals. Source: Scottish Longitudinal Study

\section{Discussion}

This study has identified changes in established employment-related patterns of health and trends across different sectoral categories. By adopting a longitudinal approach, it has revealed that in the case of self-assessed morbidity, which acts as a proxy of premature mortality (Bentham, Eimermann, Haynes, Lovett \& Brainard, 1995), employment in the manufacturing sector has a protective effect, even after socioeconomic controls are in place - but this only applies to men. This could be due to the fact that this study covers a relatively contemporary time period (the 1990s) which captures changes to industrial sub-sectoral composition and improved safety practices across the manufacturing sector. More technologically advanced industries can possibly provide safer working environments and the time frame included in the analysis captures this change. In addition, industrial working environments include a more highly educated labour composition than in the past. More precisely, contemporary manufacturing industries, in an effort to be more innovative and remain internationally competitive, employ highly qualified individuals in posts where manual effort may be present but is minimal and sits alongside an increased premium on problem-solving and communication skills. This trend demonstrates a transition from traditional manual heavy engineering towards lighter and less labourintensive manufacturing industries that lead to a reduction in physical risks. In construction, there has also been automation of some heavily physical tasks, but here improvements in health and safety practices may have had a transformative effect in reducing occupational hazards.

Sectoral and gender differentiation of the results have implications for our understanding of the health impacts of employment. High levels of customer pressure and employer productivity demands, leading to imbalance of work and personal life as well as physical impacts of long periods of sitting in sedentary jobs, such as musculoskeletal disorders and increased levels of obesity (Biddle et al., 2010; Lundberg, 1999; Sekine et al., 2009; Stansfeld, North, White \& Marmot, 
1995) can explain some of the health impacts in the service sector. Consequently, daily and long-term exposure in a sedentary working environment combined with an overall sedentary lifestyle is linked to cardiovascular mortality, diabetes, cancer and metabolic dysfunction (Biddle et al., 2010). The high-paid service sector appears to be particularly harmful to men's health.

There are important differences between the manufacturing and service sectors in the impact on health of changing industry within each of these sectors. Specifically, changing industrial sector within manufacturing is associated with lowered probability of an individual reporting poor health, whereas the opposite is the case in the service sector, where those changing sector within services are more likely to report poor health. This may reflect effective labour market matching taking place within the manufacturing sector, i.e. job changes result in better matches between worker and job. It may also be that training for new entrants to an industry is more effective in manufacturing than in services.

The association of transition within manufacturing with reduced likelihood of morbidity is true for men and women (although the results for women are not statistically significant, the odds ratios point in the same direction as for men). Nevertheless men still have higher odds of morbidity compared to women, especially for those employed in the service sector. This finding, that men are more likely to report poor health, is in contrast to numerous studies which have repeatedly shown that women report greater levels of poor health than men. Our finding, however, arises after controlling for industry of employment, indicating that men are more likely than women to work in industrial sectors that are protective of health. Furthermore, our sample includes the employed population, thus the sample size of women in some groups, especially manufacturing, may not be sufficient to produce significant results. Moreover, domestic rather than occupational aspects of women's lives may have a greater influence on their health compared to men, as suggested in existing literature.

There are two possible interpretations of these outcomes. One is that job matching and training are better in manufacturing, which minimises job stress that can result from poor hiring decisions or inadequate training perhaps more prevalent in the service sector. Therefore, the health impact of changing sector within services may reflect poor labour market matching within the service sector, for example arising from labour shortages and/or poor screening and hiring practices. It may also be the result of low levels of training producing 'job stress' and subsequent adverse health outcomes. An alternative interpretation, however, is that in manufacturing there are barriers to entry which make it more difficult for those with poor health to change industry of employment, for example arising from physical demands of jobs and/or health and safety or productivity concerns with hiring people with poor health - whereas there may be more opportunities to change sub-sector of employment in response to deteriorating health within the service sector.

\section{Conclusion}

The results suggest that employment in the manufacturing sector has a protective impact on health, especially for men, whereas employees in the service sector are more likely to report morbidity. This is a significant break with the past, when manufacturing and manual employment has been linked with poorer health. Likewise, the movement of an individual from manufacturing to low-paid service sector is associated with health deterioration. The ongoing decline of employment in manufacturing and growth in the low-paid service sector, therefore, suggest that sectoral change in the labour market is having an adverse impact on health. The gendered variations of occupational transitions imply that male employees are more susceptible to the health implications of these changes. Overall, there is a shift in morbidity risk from conventionally hazardous sectors of employment, such as manufacturing, to services. This implies that contemporary labour market conditions are accompanied with new occupational hazards related to the nature of the job and the working environment in the service sector.

As a result, individual level health implications of the labour market appear to operate at two levels: first, exposure to stressful working environments in the service secto; and second, difficult transitions between sectors in the labour market. Consequently, labour market policies should consider these two elements, since the requirements for policy implications may vary. The current labour market is characterised by a rise in 
precarious forms of employment and intensification of work, especially for the low-skilled service sector jobs. Therefore, policies should focus on improving conditions related to the nature of the job and the working environment. For example, hiring practices incorporating training provision and support for staff development can create more satisfactory employment settings and promote career progression.

When transition occurs to another type of job within the same or in a different sector, effective labour markets (e.g. in providing good information about jobs and individuals) should help produce a good fit between worker and job, especially for lowskilled employees, who are more vulnerable to frequent and involuntary transitions. On the whole, transitions have become an integral part of an individual's employment history, as the 'job for life' has declined, therefore policies should integrate appropriate planning that will take into account the importance of skills and retraining, leading to more productive and less stressful adaptions to new working environments.

Consequently, future research should reflect upon the complexities of different types of employment, especially types of precarious jobs, among various sub-sectors of the economy and their connection with morbidity outcomes. Research is required in particular to understand the health impacts of new occupational hazards that appear to be emerging in the low-skilled service sector. In parallel to this, exploring detailed employment histories will shed some light on the mechanisms of association between occupational transitions and health. In addition, investigating the scope for re-employment in response to changes in health in different industries is an important area for further research, including the role of employers' occupational health practices.

\section{Acknowledgements}

The help provided by staff of the Longitudinal Studies Centre - Scotland (LSCS) is acknowledged. The LSCS is supported by the ESRC/JISC, the Scottish Funding Council, the Chief Scientist's Office and the Scottish Government. The authors alone are responsible for the interpretation of the data. Census output is Crown copyright and is reproduced with the permission of the Controller of HMSO and the Queen's Printer for Scotland.

\section{References}

Anderson, V., Schulte, P., Sestito, J., Linn, H., \& Nguyen, L. (2010). Occupational fatalities, injuries, illnesses, and related economic loss in the wholesale and retail trade sector. American Journal of Industrial Medicine, 53(7),673-685. http://dx.doi.org/10.1002/ajim.20813

Andersson, E., Persson, B., Bryngelsson, I.L., Magnuson, A., \& Westberg, H. (2010). Cancer mortality in a Swedish cohort of pulp and paper mill workers. International Archives of Occupational and Environmental Health, 83(2), 123-132. http://dx.doi.org/10.1007/s00420-009-0446-1

Aronsson, G., Gustafsson, K., \& Dallner, M. (2002). Work environment and health in different types of temporary jobs. European Journal of Work and Organizational Psychology, 11(2),151-175. http://dx.doi.org/10.1080/13594320143000898

Arrow, J.O. (1996). Estimating the influence of health as a risk factor on unemployment: a survival analysis of employment durations for workers surveyed in the German Socio-Economic Panel (1984-1990). Social Science and Medicine, 42(12),1651-1659. http://dx.doi.org/10.1016/0277-9536(95)00329-0

Bambra, C., \& Eikemo, T.A. (2009). Welfare state regimes, unemployment and health: a comparative study of the relationship between unemployment and self- reported health in 23 European countries. Journal of Epidemiology and Community Health, 63(2),92-98. http://dx.doi.org/10.1136/jech.2008.077354

Bambra, C., Gibson, M., Sowden, A., Wright, K., Whitehead, M., \& Petticrew, M. (2010). Tackling the wider social determinants of health and health inequalities: evidence from systematic reviews. Journal of Epidemiology and Community Health, 64(4), 284-291. http://dx.doi.org/10.1136/jech.2008.082743

Bartley, M. (1994). Unemployment and ill health: understanding the relationship. Journal of Epidemiology and Community Health, 48(4),333-337. http://dx.doi.org/10.1136/jech.48.4.333 
Bartley, M. (1999). Measuring women's social position: The importance of theory. Journal of Epidemiology and Community Health, 53(10),601-602. http://dx.doi.org/10.1136/jech.53.10.601

Baumberg, B. (2014). Fit-for-Work - or Work Fit for Disabled People? The Changing Role of Job Demands and Control in Incapacity Claims. Journal of Social Policy, 43(2),289-310.

http://dx.doi.org/10.1017/S0047279413000810

Beatty, C., \& Fothergill, S. (1996). Labour Market Adjustment in Areas of Chronic Industrial Decline: The Case of the UK Coalfields. Regional Studies, 30(7),627-640. http://dx.doi.org/10.1080/00343409612331349928

Beatty, C., Fothergill, S., \& Powell, R. (2008). Women on Incapacity Benefits: New Survey Evidence. Sheffield: CRESR.

Benach, J., Muntaner, C., \& Santana, V. (2007). Employment conditions and health inequalities. Final Report to the WHO Commission on Social Determinants of Health. Geneva: WHO.

Benach, J., Vives, A., Amable, M., Vanroelen, C., Tarafa, G., \& Muntaner, C. (2014). Precarious employment: understanding an emerging social determinant of health. Annual Review of Public Health. 35, 229253. http://dx.doi.org/10.1146/annurev-publhealth-032013-182500

Bender, K.A., Donohue, S.M., \& Heywood, J.S. (2005). Job satisfaction and gender segregation, Oxford Economic Papers, 57(3),479-496. http://dx.doi.org/10.1093/oep/gpi015

Bentham, G., Eimermann ,J., Haynes, R., Lovet,t A., \& Brainard, J. (1995). Limiting long-term illness and its associations with mortality and indicators of social deprivation. Journal of Epidemiology and Community Health, 49 (Supplement 2), S57-S64. http://dx.doi.org/10.1136/jech.49.Suppl_2.S57

Biddle, S., Cavill, N., Ekelund, U., Gorely ,T., Griffiths, M. D. \& Jago, R. (2010). Sedentary behaviour and obesity: review of the current scientific evidence. London: Department of Health / Department For Children, Schools and Families.

Booker, C.L., \& Sacker, A. (2013). Labour force sequences, unemployment spells and their effect on subjective well-being set points. Longitudinal and Life Course Studies, 4(2), 88-104

Booth, A.L., Francesconi, M. \& Frank,J. (2002). Temporary Jobs: Stepping Stones or Dead Ends. The Economic Journal, 112(480), F189-F213. http://dx.doi.org/10.1111/1468-0297.00043

Brown, J., Demou ,E., Tristram, M.A., Gilmour, H., Sanati, K.A., \& MacDonald, E. (2012). Employment status and health: understanding the health of the economically inactive population in Scotland. BMC Public Health, 12,327. http://dx.doi.org/10.1186/1471-2458-12-327

Burström, B., \& Fredlund, P. (2001). Self-rated health: is it as good a predictor of subsequent mortality among adults in lower as well as in higher social classes? Journal of Epidemiology and Community Health, 55(11), 836-840. http://dx.doi.org/10.1136/jech.55.11.836

Campos-Serna, J., Ronda-Pérez, E., Artazcoz, L., Moen, B.E. \& Benavides, F.G. (2013). Gender inequalities in occupational health related to the unequal distribution of working and employment conditions: a systematic review. International Journal for Equity in Health, 12,57. http://dx.doi.org/10.1186/14759276-12-57

Danson, M. (2005). Old Industrial Regions and Employability. Urban Studies, 42(2),285-300. http://dx.doi.org/10.1080/0042098042000316155

De Grip, A., Bosma, H., Willems, D. \& Van Boxtel, M. (2008). Job-worker Mismatch and Cognitive Decline, Oxford Economic Papers, 60(2), 237-253. http://dx.doi.org/10.1093/oep/gpm023

Eliason ,M. \& Storrie, D. (2009). Does job loss shorten life? Journal of Human Resources, 44(2),277-302. http://dx.doi.org/10.3368/jhr.44.2.277

Eriksson, I., Unden, A.L. \& Elofsson, S. (2001) Self-rated health. Comparisons between three different measures. Results from a population study. International Journal of Epidemiology. 30(2),326-333. http://dx.doi.org/10.1093/ije/30.2.326

Fernandez, R.M., \& Mors, L.M. (2008). Competing for Jobs: Labor Queues and Gender Sorting in the Hiring Process. Social Science Research, 37,1061-1080. http://dx.doi.org/10.1016/j.ssresearch.2007.10.003

Ferrie, J.E., Shipley, M.J., Stansfeld, S.A. \& Marmot, M.G. (2002). Effects of chronic job insecurity and change in job security on self-reported health, minor psychiatric morbidity, physiological measures, and 
health related behaviours in British civil servants: the Whitehall II study. Journal of Epidemiology and Community Health, 56(6), 450-454. http://dx.doi.org/10.1136/jech.56.6.450

Fieldhouse, E. \& Hollywood, E. (1999) Life After Mining: Hidden Unemployment and Changing Patterns of Economic Activity amongst Miners in England and Wales, 1981-1991. Work, Employment \& Society, 13(3),483-502.

Gesthuizen, M. \& Dagevos, J. (2008). Mismatching of persons and jobs in the Netherlands: consequences for the returns to mobility. Work, Employment \& Society, 22(3),485-506. http://dx.doi.org/10.1177/0950017008093482

Hampson, l., \& Junor, A. (2010). Putting the process back in: Rethinking service sector skill. Work, Employment \& Society 24(3),526-545. http://dx.doi.org/10.1177/0950017010371664

Hedlund, U., Järvholm, B., \& Lundbäck, B. (2006). Persistence of respiratory symptoms in ex-underground iron ore miners. Occupational Medicine, 56(6),380-385. http://dx.doi.org/10.1093/occmed/kql035

Hein, M.J., Stayner, L.T., Lehman, E., \& Dement, J.M. (2007). Follow-up study of chrysotile textile workers: cohort mortality and exposure-response. Occupational and Environmental Medicine, 64(9),616-625. http://dx.doi.org/10.1136/oem.2006.031005

Holdsworth, C. (2010). Patterns of pay: results of the Annual Survey of Hours and Earnings 1997 to 2009. Economic and Labour Market Review, 4(3),59-70. http://dx.doi.org/10.1057/elmr.2010.38

Hoque, K. \& Kirkpatrick, I. (2003). Non-standard employment in the management and professional workforce: Training, consultation, and gender implications. Work, Employment \& Society, 17(4),67689. http://dx.doi.org/10.1177/0950017003174004

Idler, E.L. \& Benyamini ,Y. (1997). Self-rated health and mortality: a review of twenty-seven community studies. Journal of Health and Social Behavior, 38(1), 21-37. http://dx.doi.org/10.2307/2955359

Jones, M.K., Jones, R.J., Latreille, P.L. \& Sloane, P.J. (2009). Training, Job Satisfaction, and Workplace Performance in Britain: Evidence from WERS. Labour, 23(s1), 139-175. http://dx.doi.org/10.1111/j.1467-9914.2008.00434.x

Jones, D.R., Sutton, A.J., Abrams, K.R., Fenty, J., Warren, F.,\& Rushton, L. (2009). Systematic review and meta-analysis of mortality in crop protection product manufacturing workers. Occupational and Environmental Medicine, 66(1),7-15.http://dx.doi.org/10.1136/oem.2007.035733

Kessler, R.C., Turner, J.B. \& House, J.S. (1989). Unemployment, reemployment and emotional functioning in a community sample. American Sociological Review, 54(4),648-657. http://dx.doi.org/10.2307/2095885

Kiecolt-Glaser, J. K. \&Newton, T. L. (2001). Marriage and health: His and hers. Psychological Bulletin, 127(4), 472-503. http://dx.doi.org/10.1037/0033-2909.127.4.472

Korpi, T. (2001). Accumulating Disadvantage. Longitudinal Analyses of Unemployment and Physical Health in Representative Samples of the Swedish Population. European Sociological Review, 17(3),255-273. http://dx.doi.org/10.1093/esr/17.3.255

Kreimer, M. (2004). Labour market segregation and gender-based division of labour. European Journal of Women's Studies, 11(2),223-246. http://dx.doi.org/10.1177/1350506804042097

Krieger, N. (2003). Genders, sexes, and health: what are the connections - and why does it matter? International Journal of Epidemiology, 32(4),652-657. http://dx.doi.org/10.1093/ije/dyg156

Kristensen, N., \& Westergaard-Nielsen, N. (2004). Does Low Job Satisfaction Lead to Job Mobility? IZA Discussion Paper No.1026. Accessed 25th September: http://ssrn.com/abstract $=511722$

Kuper, H., \& Marmot, M. (2003). Job strain, job demands, decision latitude, and risk of coronary heart disease within the Whitehall II study. Journal of Epidemiology and Community Health, 57(2),147153. http://dx.doi.org/10.1136/jech.57.2.147

Lahelma, E., Maritkainen, P., Laaksonen, M., \& Aittomäki, A. (2004). Pathways between socioeconomic determinants of health. Journal of Epidemiology and Community Health, 58 (4),327-332. http://dx.doi.org/10.1136/jech.2003.011148

Liljegren , M., \& Ekberg, K. (2010). Job mobility as predictor of health and burnout, Journal of Occupational and Organizational Psychology, 82(2),317-329. http://dx.doi.org/10.1348/096317908X332919 
Lindholm, C., Burström, B., \& Diderichsen, F., (2001). Does chronic illness cause adverse social and economic consequences among Swedes? Scandinavian Journal of Public Health, 29(1),63-70. http://dx.doi.org/10.1177/14034948010290011201

Loomis, D., Richardson, D.B., Bena, J.F. \& Bailer, A.J. (2004). Deindustrialisation and the long term decline in fatal occupational injuries. Occupational and Environmental Medicine, 61(7),616-621. http://dx.doi.org/10.1136/oem.2003.009571

Lundberg, U. (1999). Stress Responses in Low-Status Jobs and Their Relationship to Health Risks: Musculoskeletal Disorders. Annals of the New York Academy of Sciences, 896(1),162-172. http://dx.doi.org/10.1111/j.1749-6632.1999.tb08113.x

Lundberg, O., \& Manderbacka, K. (1996). Assessing the reliability of a measure of self-rated health. Scandinavian Journal of Public Health 24(3),218-224. http://dx.doi.org/10.1177/140349489602400314

Macintyre, S., Ellaway, A., Hiscock, R., Kearns, A., Der, G., \& McKay, L. (2003). What features of the home and the area might help to explain observed relationships between housing tenure and health? Evidence from west Scotland. Health and Place, 9(3), 207-218. http://dx.doi.org/10.1016/S13538292(02)00040-0

Mackenbach, J.P., Van den Bos ,J., Joung, I.M., Van de Mheen, H. \& Stronks, K. (1994). The determinants of excellent health: different from the determinants of ill-health? International Journal of Epidemiology, 23(6),1273-1281. http://dx.doi.org/10.1093/ije/23.6.1273

Madero-Cabib, I. (2015). The life course determinants of vulnerability in late careers. Longitudinal and Life Course Studies, 6(1),88-106. http://dx.doi.org/10.14301/llcs.v6i1.299

Marmot, M., \& Bell, R. (2010). Challenging health inequalities-implications for the workplace. Occupational Medicine, 60 (3),162 - 164. http://dx.doi.org/10.1093/occmed/kqq008

Marmot, M.G., Smith, G.D., Stansfeld, S., Patel,C., North, F., Head, J., White, I., Brunner, E., \& Feeney, A. (1991). Health inequalities among British civil servants: the Whitehall II study. Lancet, 337 (8754), 1387-93. http://dx.doi.org/10.1016/0140-6736(91)93068-K

Menéndez. M., Benach, J., Muntaner, C., Amable, M., \& O'Campo, P. (2007). Is precarious employment more damaging to women's health than men's? Social Science and Medicine, 64(4), 776-781. http://dx.doi.org/10.1016/j.socscimed.2006.10.035

Montgomery, S.M., Cook, D.G., Bartley, M.J. \& Wadsworth, M.E.J. (1998). Unemployment, cigarette smoking, alcohol consumption and body weight in young British men. European Journal of Public Health, 8(1),21-27. http://dx.doi.org/10.1093/eurpub/8.1.21

Morris, J.K. \& Cook, D.G. (1991). A critical review of the effect of factory closures on health. British Journal of Industrial Medicine, 48(1),1-8. http://dx.doi.org/10.1136/oem.48.1.1

Morris, J.K., Cook, D.G. \& Shaper, A.G. (1994). Loss of employment and mortality. BMJ, 308(6937),11351139. http://dx.doi.org/10.1136/bmj.308.6937.1135

Murray, R., Baldwin, J., Ridgway, K. \& Winde, B. (2005). Socio-economic Decline and Adaptation: South Yorkshire's Former Coalfields. Local Economy, 20(4),344-359. http://dx.doi.org/10.1080/02690940500286552

Nixon, D. (2006). I just like working with my hands: employment aspirations and the meaning of work for low-skilled unemployed men in Britain's service economy. Journal of Education and Work, 19(2),201-217. http://dx.doi.org/10.1080/13639080600668051

Ostry, A.S., Barroetavena, M., Hershler, R., Kelly, S., Demers, P.A., Teschke, K. \& Hertzman, D. (2002). Effect of de-industrialisation on working conditions and self-reported health in a sample of manufacturing workers. Journal of Epidemiology and Community Health, 56(7),506-509. http://dx.doi.org/10.1136/jech.56.7.506

Ostry, A.S., Hershler, R., Kelly, S., Demers, P., Teschke, K., \& Hertzman, C. (2001). Effects of deindustrialization on unemployment, re-employment, and work conditions in a manufacturing workforce. BMC Public Health, 1(1),15. http://dx.doi.org/10.1186/1471-2458-1-15 
Ostry, A.S., Marion, S., Green, L., Teschke, K., Hershler, R., Kelly, S., \& Hertzman, C. (2000). The relationship between unemployment, technological change and psychosocial work conditions in British Columbia sawmills. Critical Public Health, 10(2),179-192. http://dx.doi.org/10.1080/713658238

Power, R. (2008). After the Black Gold: A View of Mining Heritage from Coalfield Areas in Britain. Folklore, 119(2),160-181. http://dx.doi.org/10.1080/00155870802056977

Riva, M., Terashima, M., Curtis, S., Shucksmith, J. \& Carlebach, S. (2011). Coalfield health effects: variation in health across former coalfield areas in England. Health and Place, 17(2),588-597. http://dx.doi.org/10.1016/j.healthplace.2010.12.016

Rocha, C. (2001). From plant closure to reemployment in the new economy: Risks to workers dislocated from the declining garment manufacturing industry. Journal of Sociology and Social Welfare, XXVIII(2),5375.

Sayce, S., Ackers, P., \& Green, A.M. (2007). Work Restructuring and Changing Craft Identity: The Tale of the Disaffected Weavers (or what happens when the rug is pulled from under your feet). Work, Employment \& Society, 21(1),85-101. http://dx.doi.org/10.1177/0950017007073618

Scherer, S. (2004). Stepping-stones or Traps? The Consequences of Labour Market Entry Positions on Future Careers in West Germany, Great Britain and Italy. Work, Employment \& Society, 18(2), 369-94. http://dx.doi.org/10.1177/09500172004042774

Scotland's Census (2015). Scotland's Census. Shaping our future. Accessed $18^{\text {th }}$ February from: http://www.scotlandscensus.gov.uk/variables-classification/health

Sekine, M., Chandola, T., Martikainen, P., Marmot, M., \& Kagamimori, S. (2009). Socioeconomic inequalities in physical and mental functioning of British, Finnish and Japanese civil servants: role of job demand, control and work hours. Social Science and Medicine, 69(10),1417-1425. http://dx.doi.org/10.1016/j.socscimed.2009.08.022

Siegrist., J, Starke, D., Chandola, T., Godin, I., Marmot, M., Niedhammer, I., \& Peter, R. (2004). The measurement of effort-reward imbalance at work: European comparisons. Social Science and Medicine, 58(8),1483-1499. http://dx.doi.org/10.1016/S0277-9536(03)00351-4

SLS-DSU (2013) Scottish Longitudinal Study Development and Support Unit (SLS-DSU). Accessed 2nd November from: http://sls.Iscs.ac.uk/

Stansfeld, S.A., North, F.M., White, I. \& Marmot, M.G. (1995). Work characteristics and psychiatric disorder in civil servants in London. Journal of Epidemiology and Community Health, 49(1),48-53. http://dx.doi.org/10.1136/jech.49.1.48

Stewart, J.M. (2001). The impact of health status on the duration of unemployment spells and the implications for studies of the impact of unemployment on health status. Journal of Health Economics, 20(5),781-796. http://dx.doi.org/10.1016/s0167-6296(01)00087-X

Stier, H. \& Yaish, M. (2014).Occupational segregation and gender inequality in job quality: a multi-level approach. Work Employment \& Society, 28(2), 225-246. http://dx.doi.org/10.1177/0950017013510758

Stout, N.A., Jenkins, E.L. \& Pizatella, T.J. (1996). Occupational injury mortality rates in the United States: changes from 1980 to 1989. American Journal of Public Health, 86(1),73-77.

http://dx.doi.org/10.2105/AJPH.86.1.73

Van der Hulst, M. \& Geurts, S. (2001). Associations between overtime and psychological health in high and low reward jobs. Work \& Stress, 15(3),227-240. http://dx.doi.org/10.1080/026783701110.1080/02678370110066580

Van Rossum, C.T.M., Shipley, M., Van de Mheen, H., Grobbee, D.E. \& Marmot, M. (2000). Employment grade differences in cause specific mortality. A 25 year follow-up of civil servants from the first Whitehall study. Journal of Epidemiology and Community Health, 54(3),178-184. http://dx.doi.org/10.1136/jech.54.3.178

Vermeulen, M. \& Mustard, C. (2000). Gender differences in job strain, social support at work, and psychological distress, Journal Occupational Health Psychology, 5(4),428-440. http://dx.doi.org/10.1037/1076-8998.5.4.428 
Wessel, T. (2005) Industrial Shift, Skill Mismatch and Income Inequality: A Decomposition Analysis of Changing Distributions in the Oslo Region. Urban Studies, 42(9),1549-1568. http://dx.doi.org/10.1080/00420980500185421

WHO (2016) Health Impact Assessment (HIA). World Health Organization. Accessed 16 February from: http://www.who.int/hia/evidence/doh/en/

Wijnhoven, H.A., De Vet, H.C., Picavet, H.S., (2006). Explaining sex differences in chronic musculoskeletal pain in a general population. Pain, 124(1-2),158-166. http://dx.doi.org/10.1016/j.pain.2006.04.012

Zou, M. (2015). Gender, work orientations and job satisfaction. Work, Employment \& Society, 29(1),3-22, http://dx.doi.org/10.1177/0950017014559267 